\title{
Adaptation of the Attitude toward the Subject of Chemistry Inventory (ASCI) into Turkish
}

\author{
Senol Sen ${ }^{1}$, Ayhan Yilmaz ${ }^{2}$, Senar Temel ${ }^{3}$ \\ ${ }^{1}$ Hacettepe University, Faculty of Education, Beytepe-Ankara, Turkey \\ ${ }^{2}$ Hacettepe University, Faculty of Education, Beytepe-Ankara, Turkey \\ ${ }^{3}$ Hacettepe University, Faculty of Education, Beytepe-Ankara, Turkey \\ Correspondence: Senol Sen, Hacettepe University, Faculty of Education, Beytepe-Ankara, Turkey.
}

Received: March 23, 2016 Accepted: April 22, $2016 \quad$ Online Published: April 25, 2016

doi:10.11114/jets.v4i8.1485

URL: http://dx.doi.org/10.11114/jets.v4i8.1485

\begin{abstract}
Developing an attitude influential in individuals' behaviours and related with academic achievement is a concept whose development science educators consider important. This research aims to adapt the 8-item Attitude toward the Subject of Chemistry Inventory (ASCI) - which was developed by Bauer (2008) and revised by Xu and Lewis (2011) - into Turkish, and to perform the validity and reliability analyses of the Turkish form of the inventory. Confirmatory factor analysis was performed for the validity of the inventory, and Cronbach Alpha $(\alpha)$ coefficient as well as McDonald's Omega $(\omega)$ coefficient were calculated for reliability. It was found following the confirmatory factor analysis that acceptable fit indices belonged to the model measuring two correlated different structures. It was also found in consequence of the confirmatory factor analysis that the $t$ values were significant at the level of 0.01 . Accordingly, factor loads were in the 0.31-0.84 range. Fit indices for correlated two-factor model were regarded to meet the goodness of fit criteria. Cronbach $\alpha$ coefficient was found to be 0.713 for the cognitive dimension where four items were included; and to be 0.731 for the affective dimension. McDonald's $\omega$ coefficient recommended for congeneric measurements was calculated as 0.74 for the cognitive dimension, and 0.75 for the affective dimension.
\end{abstract}

Keywords: affective dimension, attitudes toward chemistry course, cognitive dimension, confirmatory factor analysis

\section{Introduction}

The Attitudes-which have three dimensions as cognitive, affective and behavioural-occupy an important place in science education. Attitudes are an important learning output beside academic achievement. Students' development of positive attitudes towards science courses is one of science educators' fundamental objectives. Studies available indicate that science educators stress the need for school curricula to develop positive attitudes towards science as one of their most important targets (Aiken \& Aiken, 1969; Koballa, 1988; Laforgia, 1988). There are two basic reasons for the need for students to have positive attitudes. One of them is the fact that attitudes are related with academic achievement has been exhibited in the literature (Bennett, Rollnick, Green, \& White, 2001; Freedman, 1997; Germann, 1988; Haladyna \& Shauhnessy, 1982; Salta \& Tzougraki, 2004; Wilson, 1983). In a study conducted by Weinburgh (1995), for instance, it was found through meta-analysis that there was a medium level correlation between attitudes towards science courses and achievement. In a similar vein, Salta and Tzougraki (2004) also found that the correlation between high school students' achievement in chemistry and their attitudes towards chemistry course was in the 0.24-0.41 range. Bennett, et al. (2001) found that university students with lower positive attitudes towards chemistry generally received lower marks in exams. Another reason for why students should have positive attitudes is that attitudes influence individuals' behaviours (Arkonac, 2005; Glasman \& Albarracín, 2006; Kan \& Akbas, 2005; Kelly, 1988; Tavsancil, 2010). According to Arkonac (2005), an attitude is one of basic affective properties influencing behaviours and guiding behaviours. Therefore, when it is desired to change individuals' behaviours, the starting point for this should be to change the attitudes.

Innovations introduced into chemistry curriculum centre around two basic targets: to develop students' attitudes, and to improve the learning process. In order to determine the effects of these innovations, evaluations should be made to determine students' domain-specific knowledge and their attitudes. Yet, while the majority of chemistry educators are eager to evaluate students' domain knowledge of chemistry, they fail to display the same behaviour in terms of 
evaluating students' attitudes. One of the reasons for this is that educators consider attitudes as a one dimensional structure, and also that they think that attitudes can be evaluated by compiling a few good survey questions (Bauer, 2005). For this reason, while most of chemistry educators are concerned with students' cognitive properties more, they believe that affective properties are less important and act accordingly. However, studies in the literature point out that students bring their ideas, concepts and comments on happenings around them into the classroom - which make learning easier or more difficult (Chandran, Treagust, \& Tobin, 1987; Lawson, 1983; Reynolds \& Walberg, 1992). Apart from that, it is also emphasised that students' expectations in terms of learning chemistry are different from educators' expectations (Grove \& Bretz, 2007). Thus, all these indicate that the factors influential in the process of students' learning are not limited only to cognitive factors. In brief, students' affective and psychomotor experiences in addition to cognitive factors are influential in the process of learning new knowledge in a chemistry class or laboratory (Brandriet, Xu, Bretz, \& Lewis, 2011).

Since individuals' attitudes are invisible abstract concepts, they are difficult to scale. An attitude is a hidden or assumed variable. Therefore, it cannot be directly measured (Thurstone, 1967; as cited in Tavsanc1l, 2010). Because an attitude is an internal state and it cannot be observed directly, its existence can only be exhibited through observable attitude reactions (Cheung, 2009). A general picture of individuals' thoughts, feelings and behaviours is obtained, and then attempts are made to be informed of their attitudes (Thurstone, 1967, as cited in Tavsancil, 2010). On reviewing national and international literature, it was observed that various scales were developed by science educators in order to determine students' attitudes (Bauer, 2008; Bennett, et al., 2001; Berberoglu, 1990; Cheung, 2009; Geban, Ertepinar, Yilmaz, Altan, \& Sahbaz, 1994; Jenkins \& Nelson, 2005; Kan \& Akbas, 2005; Pell \& Jarvis, 2001; Tuysuz \& Tatar, 2008; Xu \& Lewis, 2011). Yet, Ramsden (1998) and Gardner (1975) stressed that theoretically deficient attitude scales are used in many studies in the literature (as cited in Cheung, 2009). This deficiency is very important to consider. Because an attitude is a multi-dimensional structure, researchers of science education should develop attitude scales on the basis of models having clearly stated dimensions and described before (Cheung, 2009). But it is observed that items included in many attitude scales used in science education are not the items about attitudes (Bennett, Lubben, \& Hogarth, 2007). Mayer and Richmond (1982) suggested researchers to revise or develop the existing scales instead of performing studies repetitive of each other in the process of developing attitude scales in science education. Cheung (2009) gathered criticisms about attitude scales in the literature under three headings: 1) most of the attitude scales used in the literature do not have a theoretical basis, 2) the multi-dimensional structure of attitude data is rarely put to confirmatory factor analysis, and 3) there are a lot of similar studies in the attitude scale development process.

\subsection{Research Focus}

Attitudes have three dimensions - namely, cognitive dimension, affective dimension, and behavioural dimension. Cognitive dimension is the information and belief in relation to attitude objects (stimulants). This dimension indicates individuals' information of attitude objects around them. Affective dimension is related with one's likes and dislikes, and it is an element of attitude changing from person to person. It contains individuals' excitement felt in relation to attitude objects. Behavioural dimension, on the other hand, reflects individuals' behavioural bias in relation to attitude objects. These biases are displayed in behaviours or gestures. This dimension involves individuals' tendency to act in compliance with their feelings, thoughts and beliefs. It is assumed that a pre-bias exists in each attitude (Tavsancil, 2010). Yet, every attitude does not need to have a behavioural element. For instance, a person can think that painting is something to enjoy, but this enjoyment does not always require that the person go to art galleries or to read books on this branch of art (Triandis, 1967; as cited in Tavsancil, 2010). Xu and Lewis (2011) pointed out that when attitudes toward science in general is available, removing the behavioural dimension from attitude scales serves better to most researchers' purpose. It is more difficult for participants to try to give realistic answers to concrete items related with behaviours than to give answers to abstract items associated with feelings and beliefs; because the desired behaviours can differ significantly in teaching environments and therefore it can be difficult to create behavioural items suitable to diverse situations and settings. For this reason, it was chosen in this research to adapt an inventory which did not contain behavioural dimension but which included only cognitive and affective dimensions. Besides, it was also found in literature review that many attitude scales used were analysed through exploratory factor analysis (Berg, 2005; Dalgety, Coll, \& Jones, 2003; Kind, Jones, \& Barmby, 2007). However, researchers such as Breckler (1984), Krosnick, Judd and Wittenbrink (2005), and Munby (1997) insisted that confirmatory factor analysis should be used in testing the validity of attitude data. Hence, also by taking into consideration the criticisms made by Cheung (2009), this research aimed to adapt Attitude toward the Subject of Chemistry Inventory (ASCI) into Turkish, and to analyse the psychometric properties of the inventory. 


\section{Method}

\subsection{Method of Research}

The survey model was used in this research. Survey model is a research approach aiming to describe a state which existed in the past or which currently exists as it is (Fraenkel \& Wallen, 2000; Karasar, 2014).

\subsection{Sample of Research}

A total of 532 prospective teachers that enrolled in general chemistry course and attending the chemistry education, primary school education and science education departments of Hacettepe, Bulent Ecevit and Cumhuriyet Universities were included in this research. The prospective teachers included in the research were in the 18-21 age range, and they were very similar in terms of socio-economic levels. Purposeful sampling method was employed in the selection of the sample. Purposeful sampling is an approach of non-random sampling which enables one to research in-depth the states rich in information in accordance with the purpose of research (Fraenkel \& Wallen, 2000).

\subsection{Instrument and Procedures}

Attitude toward the Subject of Chemistry Inventory (ASCI) was developed by Bauer (2008) in order to analyze students' attitudes toward chemistry. The inventory contained 5 sub-dimensions and 20 items. This study, however, used the version of the inventory revised by Xu and Lewis (2011). The revised version had 8 items and two sub-dimensions called cognitive dimension and affective dimension. Xu and Lewis (2011) stated that the two-dimensional inventory having cognitive and affective dimensions is more related with theoretical structure. The mentioned sub-dimensions were called intellectual accessibility and emotional satisfaction by Bauer (2008). Table 1 shows the sub-dimensions of Inventory. Scoring is between 1-7 points for each item in the inventory, and the mean score is 4 . High scores received from the inventory mean that students find the inventory intellectually accessible and emotionally satisfactory.

Table 1. The Sub-dimensions of ASCI

\begin{tabular}{llll}
\hline Sub dimensions & Item no & $\begin{array}{l}\text { Number } \\
\text { of items }\end{array}$ & Cronbach $\alpha$ \\
\hline Cognitive dimension & $1^{* * *}, 2,3$ and 6 (Xu \& Lewis, 2011) & 4 & 0.82 (Xu \&Lewis, 2011) \\
Affective dimension & $1^{* *}, 4,5$ and 10 (Bauer, 2008) & & 0.78 (Bauer, 2008) \\
& $4^{* * *}, 5^{* *}, 7^{* *}$ and 8 (Xu \& Lewis, 2011) & 4 & 0.79 (Xu \& Lewis, 2011) \\
& $14^{* *}, 7^{* *}, 11^{* *}$ and 17 (Bauer, 2008) & & 0.79 (Bauer, 2008) \\
\hline
\end{tabular}

* Cronbach $\alpha$ obtained by Bauer (2008) is the value obtained for the 5 -item dimension

*** Negative items

Firstly, the desire to adapt the Attitude toward the Subject of Chemistry Inventory (ASCI) developed by Bauer (2008) into Turkish was explained to the author in this study, and consent required was obtained. Then the inventory, which was originally in English, was translated into Turkish by two specialists, one of whom was an expert in English language and the other of whom was an expert in chemistry, and both of whom were proficient in English language. The corresponding Turkish form was created by taking into consideration the common points in the two experts' translations. The Turkish form produced was translated back into English again by the language expert. Having made the necessary regulations by field experts, the final shape was given to the Turkish form. The Turkish form was then administered to a group of 30 prospective teachers. After it was tested in terms of content and intelligibility, the final shape was given to the form. The original form and the Turkish version were given to 30 prospective teachers who were proficient in both languages at intervals of one week, and consequently it was found that there were medium level positive correlations between the cognitive and affective sub-dimensions of both inventories.

\subsection{Data Analysis}

Prior to the factor analysis of the data, Kaiser-Meyer-Olkin (KMO) Sampling Adequacy and Bartlett's Test of Sphericity were performed so as to check the fit of the data for factor analysis. The fit of data for factor analysis is tested with Bartlett's Test of Sphericity, and if the test is statistically significant, factor analysis is done. KMO, on the other hand, is a measure developed for the consistency of item/variable values. KMO offers information on whether or not data can be modelled with factor analytic model. If the KMO value is bigger than 0.50 , it can be said that a data set can be factorized (Yurdugul, n.d.). Table 2 shows the results for KMO and for Bartlett's Test of Sphericity.

Table 2. KMO and Bartlett's Test of Sphericity Results

\begin{tabular}{llll}
\hline Kaiser-Meyer-Olkin Measure of Sampling & Bartlett's Test of Sphericity & & \\
Adequacy & & & \\
\hline 0.743 & Approx. Chi-Square & df & Sig. \\
& 1081.256 & 28 & 0.000 \\
\hline
\end{tabular}

According to Table 2 , the KMO of fit test result, the value of 0.743 , shows that the data set fits the factor analysis. The fact that the result of Bartlett's Test of Sphericity is significant at the significance level of 0.05 exhibits that there are 
high correlations between variables and that the data set fits the factor analysis.

Having found that the data fitted the factor analysis, confirmatory factor analysis was performed so as to assess the construct validity of the inventory. Confirmatory factor analysis is an analysis in which attempts are made to confirm the theoretical model or structure in order to test the item and component relations of a pre-determined structure (Cokluk, Sekercioglu, \& Buyukozturk, 2012). Cronbach $\alpha$ and McDonald's $\omega$ coefficients were calculated for the reliability study of the inventory.

\section{Results}

Findings concerning the validity and reliability studies of the inventory are presented in this part. The construct validity of the inventory was tested through confirmatory factor analysis. During the validity analyses, three different models for 8 items were tested. The first one was a model in which all of the items measured only one structure, the second was a model in which 8 items which were revised and developed measured two uncorrelated different structures, and the third one was a model in which 8 items measured two correlated different structures. In consequence of the confirmatory factor analysis, it was found that acceptable fit indices belonged to the model measuring two correlated different structures. Following the confirmatory factor analysis performed, goodness of fit indices for the measurement models are shown in Table 3.

Table 3. Model-Data Fit Values for the Inventory Data

\begin{tabular}{llllllllll}
\hline \multicolumn{10}{c}{ Model-data fit indices (acceptable goodness of fit indices) } \\
\hline Model & $\chi^{2} / \mathrm{df}$ & RMSEA & SRMR & CFI & GFI & AGFI & NFI & NNFI & IFI \\
& $(<3.0)$ & $(<0.08)$ & $(<0.1)$ & $(>0.95)$ & $(>0.90)$ & $(>0.85)$ & $(>0.90)$ & $(>0.95)$ & $(>0.90)$ \\
Model I $^{*}$ & 28.593 & 0.228 & 0.16 & 0.64 & 0.79 & 0.62 & 0.63 & 0.49 & 0.64 \\
Model II $^{* *}$ & 3.675 & 0.071 & 0.096 & 0.96 & 0.97 & 0.94 & 0.94 & 0.94 & 0.96 \\
Model III $^{* * *}$ & 3.098 & 0.063 & 0.062 & 0.97 & 0.97 & 0.95 & 0.95 & 0.95 & 0.97 \\
\hline
\end{tabular}

${ }^{*}$ One-factor Model ${ }^{* * *}$ Two-factor Model (Uncorrelated) ${ }^{* * *}$ Two-factor Model (Correlated)

In consequence of the confirmatory factor analysis shown in Table 3, it was regarded that the fit indices $(\chi 2 / \mathrm{df}=3.098$, RMSEA=0.063, SRMR=0.062, CFI=0.97, GFI=0.97, AGFI=0.95, NFI=0.95, NNFI=0.95, IFI=0.97) for the two-factor (correlated) model met the goodness of fit criteria better (Celik \& Yilmaz, 2013; Cokluk et al., 2012; Schermelleh-Engel, Moosbrugger, \& Muller, 2003; Sumer, 2000). Garver and Mentzer (1999) recommended that the NNFI, CFI and RMSEA values could be taken into consideration for acceptable fit indices. Therefore, commonly used fit indices are NNFI and CFI $\left(>0.90\right.$ represents good fit), RMSEA $\left(<0.08\right.$ represents acceptable fit), and the $\chi^{2}$ statistics - which is again used very often (it is desirable that the $\chi 2 / \mathrm{df}$ proportion is smaller than 3 ) (Hoe, 2008). If the CFI value is bigger than 0.95 according to $\mathrm{Hu}$ and Bentler (1999), if it is bigger than 0.90 according to Cheng \& Chan (2003), and if SRMR is smaller than 0.08 , good fit is available between a model and the data. Sumer (2000) points out that if the $\chi^{2 / \mathrm{df}}$ proportion is smaller than 5, a model has medium level fit. Because the NNFI, CFI, RMSEA, SRMR and $\chi^{2 / d f}$ proportion have acceptable values in this study, it was taken for granted that the inventory attained construct validity. Table 4 shows the results of confirmatory factor analysis performed for the two-factor (correlated) model.

Table 4. The $\lambda_{x}, \delta, t, R^{2}, \alpha$ and $\omega$ Values Obtained as a Result of Confirmatory Factor Analysis for the Two-Factor (Correlated) Model

\begin{tabular}{llllllll}
\hline Sub-dimensions & Item no & $\lambda_{\mathrm{x}}$ & $\delta$ & $\mathrm{t}$ & $\mathrm{R}^{2}$ & $\alpha$ & $\omega$ \\
\hline \multirow{3}{*}{ Cognitive } & 1 & 0.31 & 0.90 & 6.66 & 0.10 & & \\
& 2 & 0.84 & 0.30 & 19.67 & 0.71 & 0.713 & 0.74 \\
& 3 & 0.77 & 0.40 & 17.98 & 0.59 & & \\
\hline \multirow{3}{*}{ Affective } & 6 & 0.60 & 0.64 & 13.71 & 0.36 & & \\
& 4 & 0.62 & 0.62 & 14.08 & 0.38 & & \\
& 5 & 0.79 & 0.38 & 18.36 & 0.62 & 0.731 & 0.75 \\
& 7 & 0.76 & 0.42 & 17.71 & 0.58 & & \\
\hline
\end{tabular}

Table 4 , shows the factor loads $\left(\lambda_{\mathrm{x}}\right)$, error variances $(\delta), \mathrm{t}$ values, and the explained variances for each item. The Cronbach $\alpha$ coefficient, which was the internal consistency coefficient for the reliability study of the inventory, was calculated as 0.713 for the cognitive dimension, and as 0.731 for the affective dimension. McDonald's $\omega$ coefficient recommended for congeneric measurements (for cases where factor loads were not equal) was found to be 0.74 for the cognitive dimension, and 0.75 for the affective dimension. The fact that both $\alpha$ and $\omega$ coefficients were above 0.70 indicated that the measurement results were reliable. It was found in consequence of the confirmatory factor analysis that the $\mathrm{t}$ values for the 8 items were bigger than 2.56 , and that they were significant at the level of 0.01 . It was also found that factor loads were between 0.31 and 0.84 . On examining all these values, it was taken for granted that the inventory met reliability criteria. 


\section{Discussion}

This study aimed to adapt the Attitude toward the Subject of Chemistry Inventory (ASCI) - which was developed by Bauer (2008) and revised by Xu and Lewis (2011) - into Turkish and to analyse its psychometric properties. Prior to the factor analysis of the data, KMO and Bartlett's Test of Sphericity were performed so as to check the fit of the data for factor analysis. The fact that the result of KMO test was bigger than 0.50, and that Bartlett's Test of Sphericity result was significant at 0.05 significance level revealed that the data set fitted the factor analysis. Having found that the data fitted the factor analysis, confirmatory factor analysis was performed so as to assess the construct validity of the inventory. Three different models were tested for 8 items during the validity study of the inventory. In consequence of the confirmatory factor analysis, it was found that acceptable fit indices belonged to the model measuring two correlated different structures. Following the confirmatory factor analysis, it was regarded that the fit indices $\left(\chi^{2} / \mathrm{df}=3.098, \mathrm{RMSEA}=0.063, \mathrm{SRMR}=0.062, \mathrm{CFI}=0.97, \mathrm{GFI}=0.97, \mathrm{AGFI}=0.95, \mathrm{NFI}=0.95, \mathrm{NNFI}=0.95, \mathrm{IFI}=0.97\right)$ for the two-factor (correlated) model met the goodness of fit criteria better. Due to the fact that NNFI, CFI, RMSEA, SRMR and the $\chi^{2} / \mathrm{df} \leq 5$ proportion had acceptable values, the inventory was regarded to attain construct validity. The factors obtained in consequence of confirmatory factor analysis were seen to support the factor structure of the inventory which was revised by Xu and Lewis (2011). 8 items, 4 of which were on the cognitive dimension and 4 of which were on the affective dimension, were included in the Turkish form of the inventory.

Cronbach $\alpha$ coefficient, which was the internal consistency coefficient for the reliability study of the inventory, was found as 0.713 for the cognitive dimension, and as 0.731 for the affective dimension. McDonald's $\omega$ coefficient recommended for congeneric measurements (for cases where factor loads were not equal) was found to be 0.74 for the cognitive dimension, and 0.75 for the affective dimension. The fact that both the $\alpha$ and the $\omega$ coefficients were above 0.70 indicated that the measurement results were reliable. It was found in consequence of the confirmatory factor analysis that the $t$ values for the 8 items were bigger than 2.56 , and that they were significant at the level of 0.01 . It was also found that factor loads were between 0.31 and 0.84 . On examining all these values, it was taken for granted that the inventory met reliability criteria.

In conclusion, considering the fact that attitudes - which are one of the affective properties and which are considered less important than cognitive properties by educators - are an important learning output, the importance of measuring them correctly and conveniently becomes evident. The inventory of attitude toward chemistry, whose adaptation into Turkish is conducted in this study, can contribute to the literature as an inventory capable of serving to this purpose and use by educators and teachers. Thus, when the relation of attitudes with achievement in particular are considered, it can be provided educators and teachers an opportunity to determine students' attitudes towards courses, and take the necessary precautions before probable negative attitudes affect the learning process in a negative way.

\section{References}

Aiken, L. R., \& Aiken, D. R. (1969). Recent research on attitudes concerning science. Science Education, 53, 295-305. http://dx.doi.org/10.1002/sce.3730530405

Arkonac, S. A. (2005). Sosyal Psikoloji (3. Baski) [Social Psychology (3rd Edition)]. İstanbul: Alfa Publishing.

Bauer C. F. (2008). Attitude toward chemistry: A semantic differential instrument for assessing curriculum impacts. Journal of Chemical Education, 85, 1440-1445. http://dx.doi.org/10.1021/ed085p1440

Bauer, C. F. (2005). Beyond 'Student Attitudes': Chemistry self-concept inventory for assessment of the affective component of student learning. Journal of Chemical Education, 82, 1864-1870. http://dx.doi.org/10.1021/ed082p1864

Bennett, J., Lubben, F., \& Hogarth, S. (2007). Bringing science to life: A synthesis of the research evidence on the effects of context-based and STS approaches to science teaching. Science Education, 91(3), 347-370. http://dx.doi.org/10.1002/sce.20186

Bennett, J., Rollnick, M., Green, G., \& White, M. (2001). The development and use of an instrument to assess students' attitude to the study of chemistry. International Journal of Science Education, 23(8), 833-845. http://dx.doi.org/10.1080/09500690010006554

Berberoglu, G. (1990). Kimyaya iliskin tutumlarin olculmesi [The measurement of attitudes toward chemistry]. Egitim ve Bilim, 76, 16-27.

Berg, C. A. R. (2005). Factors related to observed attitude change toward learning chemistry among university students. Chemistry Education Research and Practice, 6(1), 1-18. http://dx.doi.org/10.1039/B4RP90001D

Brandriet, A. R., Xu, X., Bretz, S. L., \& Lewis, J. E. (2011). Diagnosing changes in attitude in first-year college chemistry students with a shortened version of Bauer's semantic differential. Chemistry Education Research and 
Practice, 12(2), 271-278. http://dx.doi.org/10.1039/C1RP90032C

Breckler, S. J. (1984). Empirical validation of affect, behavior, and cognition as distinct components of attitude. Journal of Personality and Social Psychology, 47(6), 1191-1205. http://dx.doi.org/10.1037/0022-3514.47.6.1191

Celik, H. E., \& Yilmaz, V. (2013). Lisrel 9.1 ile Yapisal Esitlik Modellemesi (Yenilenmis 2. Baski) [Structural Equation Modelling with LISREL 9.1 (revised 2nd Edition)]. Ankara: Ani Publishing.

Chandran, S., Treagust, D. F., \& Tobin, K. (1987). The role of cognitive factors in chemistry achievement. Journal of Research in Science Teaching, 24(2), 145-160. http://dx.doi.org/10.1002/tea.3660240207

Cheng, S. T., \& Chan, A. C. (2003). The development of a brief measure of school attitude. Educational and Psychological Measurement, 63(6), 1060-1070. http://dx.doi.org/10.1177/0013164403251334

Cheung, D. (2009). Developing a scale to measure students' attitudes toward chemistry lessons. International Journal of Science Education, 31(16), 2185-2203. http://dx.doi.org/10.1080/09500690802189799

Cokluk, O., Sekercioglu, G., \& Buyukozturk, S. (2012). Sosyal Bilimler icin Cok Degiskenli Istatistik SPSS ve Lisrel Uygulamalari (2. Baski) [Multivariate Statistics for the Social Sciences SPSS and LISREL Applications (2nd Edition)]. Ankara: Pegem Akademi.

Dalgety, J., Coll, R. K., \& Jones, A. (2003). Development of chemistry attitudes and experience questionnaire (CAEQ). Journal of Research in Science Teaching, 40(7), 649-668. http://dx.doi.org/10.1002/tea.10103

Fraenkel, J. R., \& Wallen, N. E. (2000). How to Design and Evaluate Research in Education (4th Ed.). Boston. McGraw Hill.

Freedman, M. P. (1997). Relationship among laboratory instruction, attitude toward science and achievement in science knowledge. Journal of Research in Science Teaching, 43(4), 343-357. http://dx.doi.org/10.1002/(SICI)1098-2736(199704)34:4<343::AID-TEA5>3.0.CO;2-R

Garver, M. S., \& Mentzer, J. T. (1999). Logistics research methods: Employing structural equation modeling to test for construct validity. Journal of Business Logistics, 20(1), 33-57.

Geban, O., Ertepinar, H., Yilmaz, G., Altan, A., \& Sahbaz, F. (1994). Bilgisayar destekli egitimin ogrencilerin fen bilgisi basarilarina ve fen bilgisi ilgilerine etkisi [The effect of computer assisted education on students' science of achievement and attitude]. I. Ulusal Fen Bilimleri Egitimi Sempozyumu Bildirileri (1. National Symposium on Science Education], 15-17 Eylul 1994, Buca Egitim Fakultesi, Izmir.

Germann, P. J. (1988). Development of the attitude toward science in school assessment and its use to investigate the relationship between science achievement and attitude toward science in school. Journal of Research in Science Teaching, 25(8), 689-703. http://dx.doi.org/10.1002/tea.3660250807

Glasman, L. R., \& Albarracín, D. (2006). Forming attitudes that predict future behavior: A meta-analysis of the attitude-behavior relation. Psychological Bulletin, 132(5), 778-822. http://dx.doi.org/10.1037/0033-2909.132.5.778

Grove N., \& Bretz S. L. (2007). CHEM: an instrument to assess students' cognitive expectations for learning chemistry. Journal of Chemical Education, 84, 1524-1529. http://dx.doi.org/10.1021/ed084p1524

Haladyna, T., \& Shauhnessy, J. (1982). Attitudes toward science: A review. Science Education, 66(4), 547-563. http://dx.doi.org/10.1002/sce.3730660406

Hoe, S. L. (2008). Issues and procedures in adopting structural equation modeling technique. Journal of Applied Quantitative Methods, 3(1), 76-83.

Hu, L. T., \& Bentler, P. M. (1999). Cutoff criteria for fit indices in covariance structure analysis: Conventional criteria versus new alternatives. Structural Equation Modeling, 6, 1-55. http://dx.doi.org/10.1080/10705519909540118

Jenkins, E. W., \& Nelson, N. W. (2005). Important but not for me: Students' attitudes towards secondary school science in England. Research in Science and Technological Education, 23(1), 41-57. http://dx.doi.org/10.1080/02635140500068435

Kan, A., \& Akbas, A. (2005). Lise ogrencilerinin kimya dersine yonelik tutum olcegi gelistirme calismasi [A Study of Developing an Attitude Scale towards Chemistry]. Mersin University Journal of the Faculty of Education, 1(2), 227-237.

Karasar, N. (2014). Bilimsel arastirma yontemi: Kavramlar, Illkeler, Teknikler [Scientific research methodology: Concepts, Principles, Techniques]. Ankara: Nobel Publishing.

Kelly, A. (1988). The customer is always right: Girls' and boys' reactions to science lessons. School Science Review, 
69(249), 662-676.

Kind, P., Jones, K., \& Barmby, P. (2007). Developing attitudes towards science measures. International Journal of Science Education, 29(7), 871-893. http://dx.doi.org/10.1080/09500690600909091

Koballa, T. R. (1988). Attitude and related concepts in science education. Science Education, 72, $115-126$. http://dx.doi.org/10.1002/sce.3730720202

Krosnick, J. A., Judd, C. M., \& Wittenbrink, B. (2005). The measurement of attitudes. In D. Albarracin, B. T. Johnson, \& M. P. Zanna (Eds.), the handbook of attitudes (pp. 21-76). Mahwah, NJ: Lawrence Erlbaum Associates.

Laforgia, J. (1988). The affective domain related to science education and its evaluation. Science Education, 72 , 407-421. http://dx.doi.org/10.1002/sce.3730720402

Lawson, A. E. (1983). Predicting science achievement: The role of developmental level, disembedding ability, mental capacity, prior knowledge, and beliefs. Journal of Research in Science Teaching, 20(2), 117-129. http://dx.doi.org/10.1002/tea.3660200204

Mayer, V. J., \& Richmond, J. (1982). An overview of assessment instruments in science. Science Education, 66(1), 49-66. http://dx.doi.org/10.1002/sce.3730660108

Munby, H. (1997). Issues of validity in science attitude measurement. Journal of Research in Science Teaching, 34(4), 337-341. http://dx.doi.org/10.1002/(SICI)1098-2736(199704)34:4<337::AID-TEA4>3.0.CO;2-S

Pell, T., \& Jarvis, T. (2001). Developing attitude to science scales for use with children of ages from five to eleven years. International Journal of Science Education, 23(8), 847-862. http://dx.doi.org/10.1080/09500690010016111

Reynolds, A. J., \& Walberg, H. J. (1992). A structural model of science achievement and attitude: An extension to high school. Journal of Educational Psychology, 84(3), 371-382. http://dx.doi.org/10.1037/0022-0663.84.3.371

Salta, K., \& Tzougraki, C. (2004). Attitudes toward chemistry among 11th grade students in high schools in Greece. Science Education, 88, 535-547. http://dx.doi.org/10.1002/sce.10134

Schermelleh-Engel, K., Moosbrugger, H., \& Muller, H. (2003). Evaluating the fit of structural equation models: Tests of significance and descriptive goodness-of-fit measures. Methods of Psychological Research-Online, 8(2), 23-74.

Sumer, N. (2000). Yapisal esitlik modelleri: Temel kavramlar ve ornek uygulamalar [Structural equation modeling: Basic concepts and sample applications]. Turk Psikoloji Yazilari, 3(6), 49-74.

Tavsancil, E. (2010). Tutumların olculmesi ve SPSS ile veri analizi [Measurement of attitudes and data analysis with SPSS]. Ankara: Nobel Publishing.

Tuysuz, C., \& Tatar, E. (2008). Effect of the pre-service teachers' learning styles on chemistry achievement and attitudes. Mustafa Kemal Journal of University Social Sciences Institute, 5(9), 97-107.

Weinburgh, M. (1995). Gender differences in student attitudes toward science: A meta-analysis of the literature from 1970 to 1991. Journal of Research in Science Teaching, 32, 387-398. http://dx.doi.org/10.1002/tea.3660320407

Wilson, V. L. (1983). A meta-analysis of the relationship between science achievement and science attitude: Kindergarten through college. Journal of Research in Science Teaching, 20(3), 839-850. http://dx.doi.org/10.1002/tea.3660200906

Xu, X., \& Lewis, J. E. (2011). Refinement of a chemistry attitude measure for college students. Journal of Chemical Education, 88(5), 561-568. http://dx.doi.org/10.1021/ed900071q

Yurdugul, H. (n.d.). What measure KMO and Bartlett's test in Factor Analysis. Retrieved from http://yunus.hacettepe.edu.tr/ yurdugul/3/indir/Kuresellik.pdf

\section{Notes}

Note 1. The partial content of this article has been presented at the IV. National Chemistry Education Congress (IV. Ulusal Kimya Egitimi Kongresi), Balikesir University, Turkey.

\section{$(\mathrm{OC}) \mathrm{BY}$}

This work is licensed under a Creative Commons Attribution 3.0 License. 